\title{
Use of electromyogram telemetry to assess the behavior of the Iberian barbel (Luciobarbus bocagei Steindachner, 1864) in a pool-type fishway
}

\author{
C.M. Alexandre a,b,c , B.R. Quintella ${ }^{\mathrm{a}, \mathrm{d}, *}$, A.T. Silva ${ }^{\mathrm{b}, \mathrm{f}}$, C.S. Mateus $^{\mathrm{a}, \mathrm{c}, \mathrm{e}}$, F. Romão ${ }^{\mathrm{a}}$, P. Branco $^{\mathrm{b}}$, \\ M.T. Ferreira ${ }^{\text {b }}$, P.R. Almeida ${ }^{a, c}$ \\ a Centro de Oceanografia, Faculdade de Ciências, Universidade de Lisboa, Campo Grande, 1749-016 Lisboa, Portugal \\ b Centro de Estudos Florestais, Instituto de Agronomia, Universidade Técnica de Lisboa, Lisboa, Portugal \\ ${ }^{c}$ Departamento de Biologia, Escola de Ciências e Tecnologia, Universidade de Évora, Largo dos Colegiais 2, 7004-516 Évora, Portugal \\ ' Departamento de Biologia Animal, Faculdade de Ciências, Universidade de Lisboa, Campo Grande, 1749-016 Lisboa, Portugal \\ e Museu Nacional de História Natural e Departamento de Biologia Ambiental, Universidade de Lisboa, Rua da Escola Politécnica 58, 1250-102 Lisboa, Portugal \\ ${ }^{\mathrm{f}}$ Faculdade de Engenharia, Universidade de Manitoba, Winnipeg MB R3T 5V6, Canada
}

\section{A R T I C L E I N F O}

\section{Article history:}

Received 9 July 2012

Received in revised form

30 November 2012

Accepted 3 December 2012

Available online 3 January 2013

\section{Keywords:}

EMG transmitters

Fish passage

Cyprinids

River connectivity

Potamodromous migration

\begin{abstract}
A B S T R A C T
Decline in fish species populations due to river regulation by dams and weirs promoted the development of fishways, which are becoming one of the most common measures for the restoration of connectivity in rivers. Fishways efficiency can be species specific and thus monitoring and evaluation, and subsequent adjustments to design and hydraulic features, are required to inform potential users prior to installation. In this study we tested the applicability of electromyogram telemetry to study the swimming behavior of a cyprinid potamodromous species, the Iberian barbel Luciobarbus bocagei Steindachner, 1864, in an experimental pool-type fishway. In total, 24 barbels were used in the experiment, 12 of which were tagged with EMG radio transmitters equipped with electrodes that register muscle activity, while the other 12 untagged fish were used as control. For tagged fish, a relationship between swimming speed and EMG telemetry signals was developed in a swimming tunnel, which was later used to assess barbels swimming behavior within the experimental fishway. Tagged fish exhibited high passage success and anaerobic burst swimming was only required to move through the submerged orifices of the fishway. Barbels spent successively less time when transversing the pools in the upstream direction. Measured hydraulic variables that were related with barbels' swimming speed within the fishways were the water velocity, turbulent kinetic energy, turbulence intensity and, especially, the horizontal component of Reynolds shear stress, highlighting the importance of these parameters when designing pool-type fishways.
\end{abstract}

C 2012 Elsevier B.V. All rights reserved.

\section{Introduction}

Fragmentation and loss of aquatic habitat, originated with the construction of artificial barriers such as dams, weirs, roads or bridges, are two of the most impacting anthropogenic actions in riverine ecosystems (Dynesius and Nilsson, 1994; Jungwirth et al., 2000; Nilsson et al., 2005). In these systems, fragmentation is easy to accomplish since a single damming event is enough to isolate adjacent river segments, contributing for the dramatic decline in the range and abundance of freshwater fish (Cowx and Welcomme, 1998; Jager et al., 2001; Lucas and Baras, 2001; Lucas and Frear, 1997). Migratory fish that include river systems in their routes,

\footnotetext{
* Corresponding author at: Centro de Oceanografia, Faculdade de Ciências, Universidade de Lisboa, Campo Grande, 1749-016 Lisboa, Portugal.

Tel.: +35121750 01 48; fax: +35121750 0009 .

E-mail address: bsquintella@fc.ul.pt (B.R. Quintella).
}

namely diadromous and potamodromous species, are particularly affected by this problem (Poulet, 2007).

The continuous decline of many fish species' stocks promoted the development of fishways, which emerged as hydraulic structures built to aid the movement of fish past the barriers and are becoming one of the most common measures for the restoration of longitudinal connectivity in rivers (Alvarez-Vázquez et al., 2007; Clay, 1995; Katopodis, 2005; Knaepkens et al., 2007). The importance of such devices was recently reinforced with the development and application of water management tools, such as the European Water Framework Directive (EWFD, 2000/60/CE), which demands an effective and undisturbed migration of fish species as a key component of watershed restoration (European Commission, 2000). Pool-type fishways are the most common type of fishways built at river barriers such as small hydropower plants and weirs (Larinier, 2002; Santos et al., 2012). These structures generally consist of a series of pools, arranged in a stepped pattern, separated by cross-walls that can be equipped with submerged orifices at 
the bottom and surface notches, whereby fish move from pool to pool by leaping over the surface notches or swimming through the bottom orifices. Their main purpose is to ensure the adequate dissipation of water energy and offer resting areas for, predominantly upstream, migrating fishes (Katopodis, 2005).

Studies on fishways have provided information on how fish use these facilities during their upstream migrations. Trapping fish in fishways at dams has been commonly used to assess the number and species of fish that successfully negotiate the pass (e.g. Baras et al., 1994; Prchalová et al., 2006). Nonetheless, this method does not provide information on the effort and behavior of fish in the vicinity of the obstruction and during ascent (Lucas and Frear, 1997). Furthermore, most of the studies developed to assess the effectiveness of these structures mainly focus on diadromous species, namely salmonids, due to their high economical and recreational value (e.g. Bunt, 1999; Katopodis, 2005; Laine et al., 2002; Naughton et al., 2007), with a low emphasis given to coarse, potamodromous species, such as cyprinids, of low commercial value (Bunt et al., 2012; Puertas et al., 2012; Noonan et al., 2012; Roscoe and Hinch, 2010). Therefore, studies concerning the movements and behavior of these species are necessary, considering their biological importance on the composition of fish assemblages. This challenge is specially highlighted in Iberian rivers, where cyprinid fishes are frequently the most dominant and abundant group of species (Cabral et al., 2005; Doadrio, 2001).

Fish telemetry was reported for the first time in 1956 and since then it has been used extensively to monitor the activities and movements of migratory and resident fishes throughout the world (Cooke et al., 2004). Conventional telemetry methods only locate individuals, being useful in determining positions and movements of individual fish. Recently, biotelemetry technology has developed into a variety of highly sophisticated techniques that measure and transfer wireless information from free-swimming fish on physiological variables such as heart rate, opercular rate and muscle activity (Cooke et al., 2004). A radio transmitter was developed which detects and transmits the electromyograms (EMG) produced during axial muscle recruitment (Cooke et al., 2004; Thorstad et al., 2000). EMG are changes in bioelectrical voltage strongly correlated with strength and duration of muscle contractions and, when measured, can be used directly as indicators of the relative fish activity. This relatively recent telemetry technique offers the opportunity to obtain quantitative estimates of the metabolic costs of activity by free ranging fish released in the wild by calibrating EMG to tailbeat frequency, swimming speed or oxygen consumption (Cooke et al., 2004; Kaseloo et al., 1992). Use of EMG can provide insights into the relative swimming effort and energetic costs of migration through particular types of habitat and passage structures and it is a promising tool for watershed restoration and, in particular, for the evaluation of fishway designs where direct visual observations are frequently not possible (Hinch et al., 1996).

The Iberian barbel (Luciobarbus bocagei Steindachner, 1864) is a potamodromous cyprinid endemic to the Iberian Peninsula and occurs in a wide range of lotic and lentic habitats and in almost all the river basins of northern and central Portugal (Lobón-Cerviá and Fernández-Delgado, 1984; Magalhães, 1992; Oliveira et al., 2002). It is considered a non-threatened species in the Iberian Peninsula (Cabral et al., 2005; Doadrio, 2001). During spring, this species migrates upstream to spawn in gravel or sandy riverbed areas with fast water flow, thus being considered a reophilic species (Baras and Cherry, 1990; Baras et al., 1994; Rodríguez-Ruiz and Granado-Lorencio, 1992). This species has received some attention in recent years through studies on its migration ecology (e.g. Santos et al., 2005) and aerobic swimming capacity (Mateus et al., 2008). More recently, some work has been done to investigate the species' behavior when moving through an experimental pool-type fishway (Silva et al., 2009, 2011, 2012a,b). However, there is still a lack of knowledge about some specific aspects of Iberian cyprinids behavior within such devices and the use of newly developed technology, such as physiological telemetry, remains a powerful and untested tool to assess the influence of fishway design and associated hydraulic features on the behavior, swimming performance and energetic costs related with the fishway passage of these fish.

The main objective of this study was to test the applicability of a biotelemetry technique, the EMG telemetry, as a method to assess the behavior of $L$. bocagei in an experimental fishway. Specifically, the following questions were posed: (i) is EMG telemetry a valid method for assessing the behavior of fish within these structures?; (ii) does this species show any type of learning pattern during the negotiation of the obstacle; (iii) is this fishway configuration suitable for a cost-efficient passage of this species and (iv) which hydraulic parameters affect the barbels' swimming performance within this type of fishway. We expect this study to contribute to the validation of the electromyogram telemetry as a monitoring method for pool-type fishways and for improved knowledge and understanding of $L$. bocagei behavior during passage of this type of fishways. Data collected with this biotelemetry technique may be useful for engineers involved in watershed restoration programs to help the design of new fishways and to modify existing ones in order to improve attraction and passage efficiency and guarantee the longitudinal connectivity enhancement (Cooke et al., 2004).

\section{Methodology}

\subsection{Fish capture and tagging procedure}

Between May and July 2009 a total of 24 barbels of comparable size (mean $L_{\mathrm{t}} \pm$ S.D. $=45.1 \pm 34.3 \mathrm{~cm}$, mean $W_{\mathrm{t}} \pm$ S.D. $\left.=798.19 \pm 200.40 \mathrm{~g}\right)$ were caught in River Sorraia $\left(38^{\circ} 59^{\prime} \mathrm{N} ; 08^{\circ} 17^{\prime} \mathrm{E}\right)$, a tributary of River Tagus basin, Portugal, using an electrofishing gear (Hans Grassl EL 62 generator, DC, $600 \mathrm{~V}, 10 \mathrm{~A}$ ). Twelve of these fish were used as controls in the fishway experiments and 12 were tagged with implantable coded electromyogram radio transmitters (CEMG-R11-25; $12 \mathrm{~g}$ in air, $12 \mathrm{~mm}$ in diameter and $56 \mathrm{~mm}$ in length), manufactured by Lotek Wireless, Newmarket, Ontario. The transmitters weighted less than $2 \%$ of barbels' body weight in the air (Jepsen et al., 2002). Electromyogram transmitters detect the voltage difference (potential) between electrodes in the muscles of fish (Brown et al., 2007; Cooke et al., 2004; Enders et al., 2007). The CEMG transmitter output was detected and recorded by a portable combined receiver and data logger (SRX_400 from Lotek Wireless) through a coaxial antenna. Data were loaded into a computer for storage, processing and statistical analysis, through a RS-232 serial communication port using the software WINHOST.

The tagging procedure was similar to that described by Booth et al. (1997), Quintella et al. (2004), Thorstad et al. (2000), among others. Experimental fish were anaesthetized by immersion in 2phenoxyethanol at a concentration of $0.4 \mathrm{ml} / \mathrm{l}$ and measured for total length $\left(L_{\mathrm{t}}\right)$ and total body weight $\left(W_{\mathrm{t}}\right)$. The fish were placed on a V-shaped surgical table, ventral side up, and continuously supplied with anesthetic solution at a lower concentration $(0.3 \mathrm{ml} / \mathrm{l})$ to maintain sedation and gills oxygenation during the tagging procedure. The transmitter was placed posteriorly in the intraperitoneal cavity and the pair of gold-tipped electrodes was positioned, in parallel, into the left red axial musculature above the lateral line. The distance and location of the electrodes was standardized in order to allow a good EMG signal reception, as well as accurate and consistent comparisons of activity between individuals (Beddow and 
McKinley, 1999; Bunt, 1999; Cooke et al., 2004). The complete surgical procedure took ca. $10 \mathrm{~min}$. All fish were left to recover for 2 days in a 20001 circular fiberglass holding tank under a controlled photoperiod ( $12 \mathrm{~h}$ light: $12 \mathrm{~h}$ dark) and water temperature $\left(18 \pm 1^{\circ} \mathrm{C}\right)$.

\subsection{Calibration of CEMG transmitter output with swimming speed}

Following the 2-day recovery period, an individual calibration procedure was developed to convert CEMG transmitter output from the tagged fish into instantaneous swimming speeds. This procedure was conducted in a modified Brett-type swim tunnel (for more details on the swim apparatus see Mateus et al., 2008). In the beginning of the calibration procedure, fish underwent an acclimation period of $30 \mathrm{~min}$ in the swim chamber at a low water velocity of $c a .0 .1 \mathrm{~m} / \mathrm{s}$. Transmissions from CEMG transmitter were recorded while the fish swam at 14 different speeds $(0.2-1.5 \mathrm{~m} / \mathrm{s}$ in $0.1 \mathrm{~m} / \mathrm{s}$ increments). Each swimming speed was maintained for a maximum period of $5 \mathrm{~min}$ and CEMG readings were recorded while the fish was swimming steadily in place. Resting CEMG values were recorded when the animal was subjected to null water velocity, remaining completely motionless for the entire prescribed interval. The calibration procedure took about $4 \mathrm{~h}$ per fish, depending largely on fish behavior. The calibration procedure was videotaped with a time-synchronized digital video camera recorder (Sony DCR-PC1E). Video recordings were reviewed after testing to exclude CEMG readings that occurred when fish were not swimming steadily. The remaining CEMG readings were expressed as an average for each swimming speed. At the end of the calibration procedure, the fish were returned to the holding tank.

\subsection{Experimental fishway}

The study was conducted in an experimental full-scale pool-type fishway installed at the Hydraulics and Environment Department of the National Laboratory for Civil Engineering (LNEC), in Lisbon (Portugal). The pool-type fishway prototype was comprised of a flume ( $10 \mathrm{~m}$ long $\times 1 \mathrm{~m}$ wide $\times 1.20 \mathrm{~m}$ high $)$ on a $8.5 \%$ slope with 6 pools $(1.90 \mathrm{~m}$ long $\times 1.0 \mathrm{~m}$ wide $\times 1.2 \mathrm{~m}$ high $)$, divided by five compact polypropylene crosswalls, each equipped with a submerged orifice $(23 \mathrm{~cm} \times 23 \mathrm{~cm})$ and side walls made of acrylic glass panels. This experimental apparatus also encompassed two concrete tanks, located at the upstream and downstream end of the flume, with $1.5 \mathrm{~m}$ long $\times 1.0 \mathrm{~m}$ wide $\times 1.2 \mathrm{~m}$ high and $4.0 \mathrm{~m}$ long $\times 3.0 \mathrm{~m}$ wide $\times 4.0 \mathrm{~m}$ high, respectively. The first tank ensured that smooth flow entered the flume, while the latter was used as an acclimation chamber. For a detailed scheme of the fishway see Silva et al. (2011) and Santos et al. (2012).

\subsection{Hydraulics}

During the experiments, the flow in the fishway was $65 \mathrm{l} / \mathrm{s}$, and the mean water velocity in the submerged orifices and pools was $1.48 \mathrm{~m} / \mathrm{s}$ and $0.27 \mathrm{~m} / \mathrm{s}$, respectively. The submerged orifices were placed in an offset arrangement, which was previously found to be more beneficial for the passage of the Iberian barbel in a similar study concerning this species (Silva et al., 2012b), where it was observed a higher rate of passage success relative to a straight orifice configuration.

Instantaneous water velocity measurements were conducted using a 3D Acoustic Doppler Velocimeter (ADV) (Nortek AS), placed vertically down. This device was selected for the measurements because of its ability to correctly measure the three-dimensional velocity components $(x, y, z)$ of flowing water (Ead et al., 2004;
Guiny et al., 2003). Flow pattern and head drop $(\Delta h)$ between pools were similar in all pools $(\Delta h=0.16 \mathrm{~m})$. Consequently, measurements were made in the second downstream pool (P1) and considered representative of the hydraulic conditions within the fishway. The measurements were performed at distinct horizontal planes parallel to the flume bottom, at 25,50 and $80 \%$ of the pool mean depth $\left(h_{m}\right)$. A predefined grid of 48 measuring points was used as reference to the measurements in each plane. In total, 2500 instantaneous measurements were recorded for each sampling point. Measurements were recorded at $25 \mathrm{~Hz}$ for a sampling period of $90 \mathrm{~s}$ in each point on the grid to determine the water velocity (WV), turbulent kinetic energy (TKE), turbulence intensity (TI) and Reynolds shear stress (RSS). The 90 s sampling period was considered to be representative for an appropriate determination of mean velocity and turbulence within the pool (Silva et al., 2011). To understand and characterize the major hydraulic forces acting on the fish and affecting its upstream movement within the fishway, the RSS was determined for its three components: horizontal $(X Y$, $\left.-\overline{\boldsymbol{\rho} \mathbf{u}^{\prime} \mathbf{v}^{\prime}}\right)$, vertical $\left(X Z,-\overline{\boldsymbol{\rho} \mathbf{u}^{\prime} \mathbf{w}^{\prime}}\right)$ and transversal $\left(Y Z,-\overline{\boldsymbol{\rho v}^{\prime} \mathbf{W}^{\prime}}\right)$, with $\rho$ being the water density $\left(1000 \mathrm{~kg} / \mathrm{m}^{3}\right)$ and $u^{\prime}, v^{\prime}$ and $w^{\prime}$ are the fluctuating velocities in the $X, Y$ and $Z$ directions, respectively. To allow for comparisons, all hydraulic parameters measured were made dimensionless by using maximum flow velocity at the orifice $\left(V_{0}\right)$ (Liu et al., 2006). A more detailed description of measurement procedures, theoretical assumptions about these hydraulic variables and hydraulic patterns within the fishway (Fig. 1) are included in Silva et al. (2011, 2012b).

\subsection{Fishway experiments}

A total of 24 barbels were tested in the fishway experiment, of which 12 were tagged with CEMG transmitters. No surgery was performed on control fish, which were held under the same conditions as the experimental fish. These individuals were used to test possible effects of CEMG transmitter implantation and subsequent manipulation during the calibration procedure, by comparing the swimming behavior between transmitter-implanted fish and controls. The use of untagged fish was also important to reduce the stress of the tagged fish at the time of release in the experimental fishway since this species is commonly seen schooling during the spawning migration.

Fish behavior was monitored directly through the acrylic glass side-walls of the flume and through a glass window located in the downstream tank by means of direct observation. These observations were supplemented by video recording, using an array of two video cameras. At the beginning of the experiments, one tagged barbel and one control untagged animal were placed into the attraction pool (P0) to freely ascend the fishway. Additionally, a more detailed observation was focused on the barbels' behavior in the second downstream pool, which was considered to be representative of the hydraulic conditions in the remaining upstream pools. One camera was placed near the side wall of this pool (lateral view) and another one was positioned above the water surface, facing downwards (top view). Both cameras were placed at a fixed distance from the pool. A reference grid of cells was placed above the pool and guiding lines representing the three horizontal planes $(0.25,0.50$ and 0.80$)$, were placed near the side wall to aid in the video monitoring process. Each trial was conducted for a maximum duration of $180 \mathrm{~min}$. CEMG readings from the transmitters signal were used to determine the swim speed of $L$. bocagei in the fishway, based on the calibration curve equation.

Video records of the second downstream pool were analyzed using the IVision Labview software from National Instruments Corporation, allowing the collection of exact location and timing of fish positions within the pool. A fish was considered to occupy one 

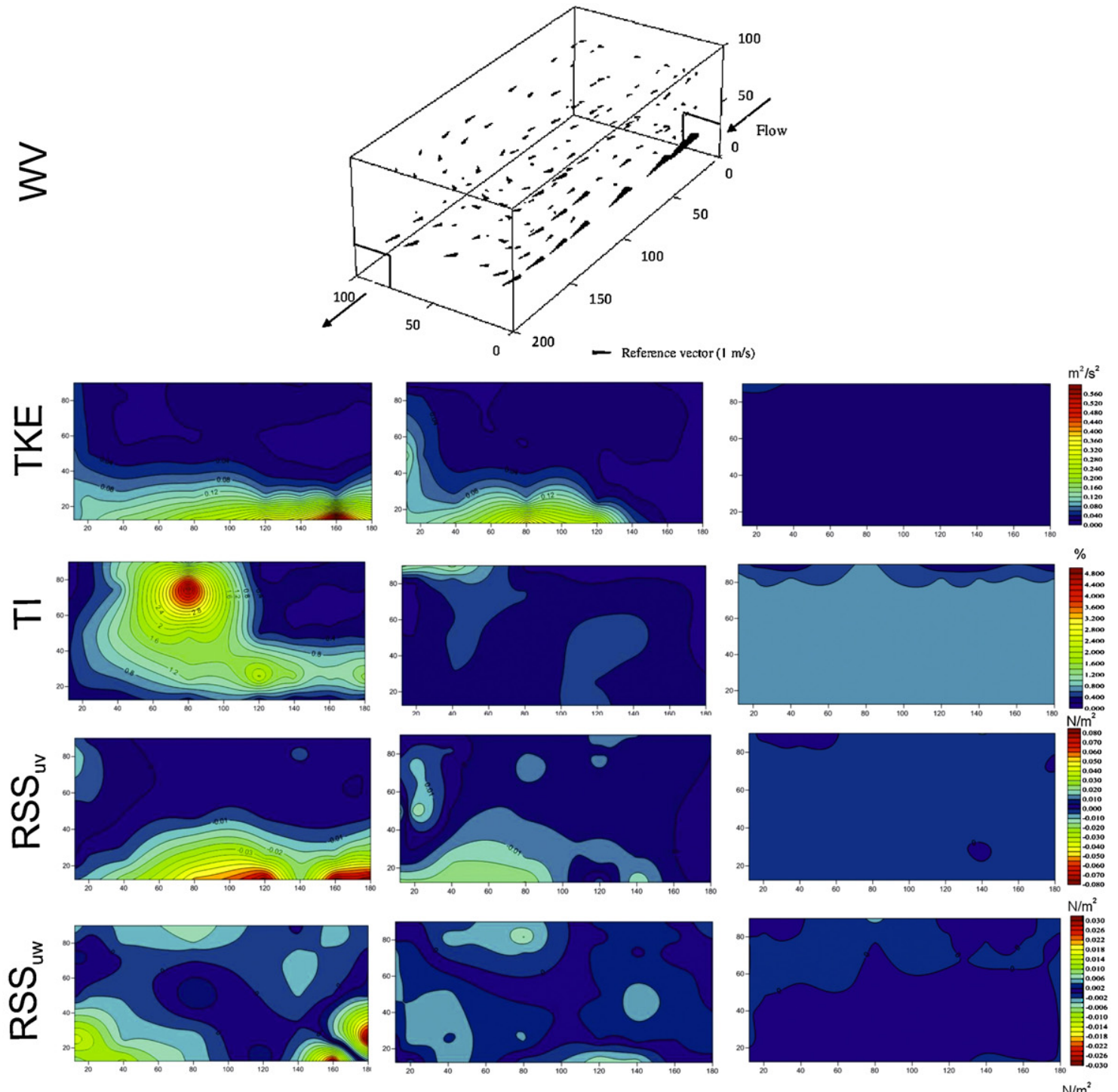

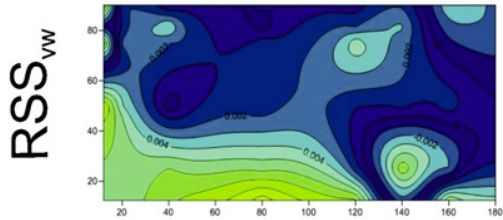

$0.25 \mathrm{hm}$

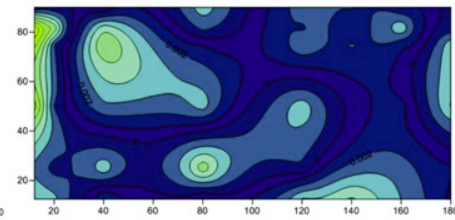

$0.50 \mathrm{hm}$

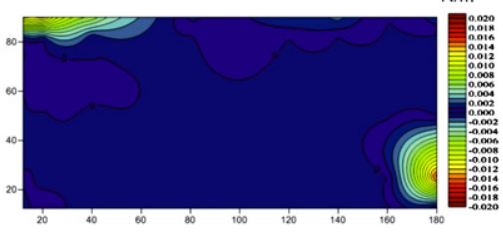

$0.80 \mathrm{hm}$

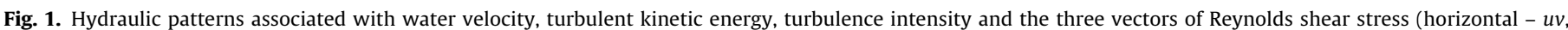

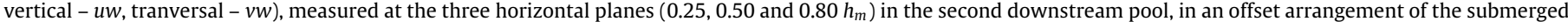

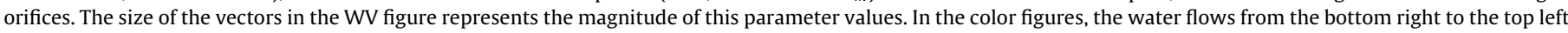
side.

cell, when more than half of its body length was within a cell's boundaries.

\subsection{Statistical analysis}

Regression analysis between average CEMG transmitter output (dependent variable) and swimming speed (independent variable) was performed for all fish successfully calibrated in the experiment. The adopted model was exponential because it was the best adjustment to the data. An analysis of covariance (ANCOVA) was used to compare the linear slopes and intercepts of the relationships between individuals and transmitters output (independent variable), using swimming speed as covariate. The objective of this analysis was to test if individual CEMG transmitters produce significantly different results in different fishes and to assess if a single calibration equation could be used in future studies to calculate swimming speed for all tagged fish.

To assess if the tagging procedure influenced the behavior of the tested barbels, Mann-Whitney $U$-tests were used to compare the behavior of tagged and control barbels regarding their passage time in each one of the four pools and the total amount of time they took to ascend the fishway during their first complete passage. 
Swimming speed values, derived from the EMG signal recorded during fishway trials, were grouped in eight classes $(0-0.2 ; 0.2-0.4$; $0.4-0.6 ; 0.6-0.8 ; 0.8-1.0 ; 1.0-1.2 ; 1.2-1.4 ;>1.4 \mathrm{~m} / \mathrm{s}$ ) for analysis of swimming speed frequency distribution. A one-way PERMANOVA analysis was performed to compare barbel swimming speed frequency distribution between each one of the pools (P1-P4) during their first ascent of the fishway. This analysis was performed using the add-on package PERMANOVA for PRIMER+v6.0 (Anderson et al., 2008).

Kruskal-Wallis tests, with a Simultaneous Test Procedure (STP) (Siegel and Castellan, 1988) for multiple comparisons, were used to compare the average swimming speed and passage time exhibited by the barbels in each one of the pools. The same analysis was applied to compare the average swimming speed in the attraction pool (P0) among the group of fish that did not enter the fishway, the group that entered the fishway but did not successfully ascend the entire fishway and the group of fish that successfully ascend the entire fishway.

A Wilcoxon signed-rank test was used to test the differences in the total time spent to ascend the fishway in the first and second passages by the fish that successfully negotiated the fishway at least two times. A Goodness-of-Fit test (Sokal and Rohlf, 1981) was conducted to compare the swimming speed frequencies distribution between the first (expected values) and second (observed values) ascent of the fishway for each barbel.

Correlations between swimming speed values and mean velocity, turbulent kinetic energy, turbulence intensity and threedimensional Reynolds shear stresses were analyzed using the Spearman rank coefficient. All statistical analyses, with the exception of PERMANOVA, were conducted with R package (v2.11.1).

\section{Results}

\subsection{Calibration of CEMG transmitter output with swimming speed}

No mortality occurred as a result of the surgical procedure used to implant the transmitters and no infection was detected around the incision area. At the end of each complete experimental procedure, the barbels were sacrificed to confirm correct electrode placement and there was no evidence of internal damage from the implantation of the tag and electrodes. Apparently, electrodes remained in place $(7.37 \mathrm{~mm} \pm 1.35$ average distance between electrodes), though minor displacement may have occurred but did not result in perceptible change in the EMG signal. All successfully calibrated fish exhibited a strong relationship $\left(R^{2}\right.$ ranged between 0.744 and $0.960 ; P<0.001$ ) between CEMG transmitter output and swimming speed (Table 1). The ANCOVA analysis conducted to test the possibility of using the same calibration equation for all animals tagged with the CEMG transmitters revealed significant differences in the intercepts $\left(F_{11,124}=6527.281 ; P<0.001\right)$ and slopes $\left(F_{11,113}=4.812 ; P<0.001\right)$ of the linear regressions of the tagged barbels. Therefore, individual calibration of CEMG transmitter output with swimming speed was performed for each tagged barbel used in the subsequent analyses.

\subsection{Experimental fishway study}

No behavioral differences were observed between the fish tagged with the transmitters and the untagged fish used as control, since Mann-Whitney tests revealed no significant differences between the time spent by each group of barbels in each one of the four pools (maximum $U=42.00 ; P>0.05$ ) and the total amount of time they spent to ascend the fishway $(U=41.00$, $P>0.05$ ).

Within the tagged barbels released in P0, 75\% $(N=9)$ managed to enter the fishway within the trial period while the remaining $25 \%(N=3)$ did not leave the attraction pool. From the nine tagged barbels that entered the fishway, seven managed to arrive at the upstream end of the fishway while two did not achieve the upstream end within the trial period and only reached one of the four intermediate pools (P1-P4). These fish presented some activity in the pools allowing the record of suitable behavioral data (Table 2). All of the untagged control barbels managed to enter the fishway and $67 \%$ of them reached the upstream end of the fishway.

The PERMANOVA analysis conducted to test differences in swimming speed frequency distributions did not revealed significant differences between any of the pools $(F=0.449 ; P=0.734)$. Frequency distributions of swimming speeds in P1-P4 are represented in Fig. 2. The Kruskal-Wallis analysis conducted to test differences in barbels' average swimming speeds, also did not reveal significant differences between the pools $\left(\chi^{2}=1.273\right.$; $P=0.757)$. On the contrary, the same analysis revealed significantly different passage times between the four pools $\left(\chi^{2}=16.157\right.$; $P<0.001)$. The test for multiple comparisons (STP) revealed that barbels significantly spent more time negotiating P1 than the other pools (Fig. 3a). For these analyses, only the seven barbels that completely ascended the fishway into the upstream pool, at least once, were considered.

The average swimming speed in the attraction pool (P0) was significantly different between the three groups of barbels clustered considering their performance in the fishway ascent (i.e. not entered, entered or passed) (Kruskall-Wallis test; $\chi^{2}=6.471$; $P<0.05)$. The simultaneous test revealed a lower average swimming speed in $\mathrm{PO}$ for the barbels that did not left the attraction pool during the entire fishway trial, intermediate for those that only entered in the fishway and the higher activity levels where detected among the barbels that passed the entire fishway structure (Fig. 3b).

Table 1

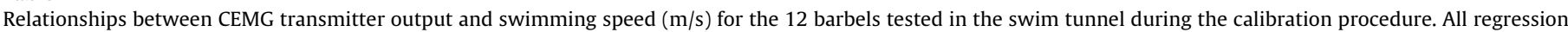
models were highly significant $(P$-value $<0.001)$.

\begin{tabular}{|c|c|c|c|c|c|}
\hline Barbel ID & Surgery date & Calibration date & Fishway trial date & Calibration equation & $R^{2}$ \\
\hline \#86 & 18-05-2009 & 21-05-2009 & 22-05-2009 & $y=2.824 \mathrm{e}^{1.084 x}$ & 0.907 \\
\hline \#87 & 18-05-2009 & 21-05-2009 & $22-05-2009$ & $y=2.565 \mathrm{e}^{0.732 x}$ & 0.816 \\
\hline \#90 & 25-05-2009 & $28-05-2009$ & $29-05-2009$ & $y=2.165 \mathrm{e}^{0.749 x}$ & 0.858 \\
\hline \#91 & 25-05-2009 & 28-05-2009 & 29-05-2009 & $y=2.311 \mathrm{e}^{0.804 x}$ & 0.729 \\
\hline \#94 & 01-06-2009 & 04-06-2009 & 05-06-2009 & $y=5.462 \mathrm{e}^{0.671 x}$ & 0.807 \\
\hline \#95 & 01-06-2009 & 04-06-2009 & 05-06-2009 & $y=3.678 \mathrm{e}^{1.213 x}$ & 0.940 \\
\hline \#98 & 08-06-2009 & 11-06-2009 & $12-06-2009$ & $y=5.111 \mathrm{e}^{0.708 x}$ & 0.858 \\
\hline \#99 & 08-06-2009 & 11-06-2009 & $12-06-2009$ & $y=3.261 \mathrm{e}^{1.155 x}$ & 0.900 \\
\hline \#102 & 15-06-2009 & 18-06-2009 & 19-06-2009 & $y=5.614 \mathrm{e}^{1.139 x}$ & 0.862 \\
\hline \#103 & $15-06-2009$ & $18-06-2009$ & 19-06-2009 & $y=3.420 \mathrm{e}^{1.484 x}$ & 0.960 \\
\hline \#106 & $22-06-2009$ & 25-06-2009 & $26-06-2009$ & $y=9.056 \mathrm{e}^{0.565 x}$ & 0.744 \\
\hline \#107 & 22-06-2009 & 25-06-2009 & $26-06-2009$ & $y=4.789 e^{0.823 x}$ & 0.916 \\
\hline
\end{tabular}


Table 2

Data on individual barbels tested in the fishway.

\begin{tabular}{|c|c|c|c|c|c|c|}
\hline Barbel ID & Time in $\mathrm{PO}$ (min) & Total time in pools (min) & $\overline{S S}$ in $\mathrm{P} 0(\mathrm{~m} / \mathrm{s})$ & $\overline{S S}$ in pools $(\mathrm{m} / \mathrm{s})$ & \% Time above $U_{\text {crit }}$ & Ascent of the fishway \\
\hline \#86 & 72.3 & 21.0 & 0.59 & 0.43 & 10.7 & Passed \\
\hline \#87 & 180.0 & 0.0 & 0.34 & - & 3.4 & Not entered \\
\hline \#90 & 145.5 & 34.5 & 0.42 & 1.02 & 32.9 & Entered \\
\hline \#91 & 75.3 & 15.3 & 0.62 & 0.71 & 17.3 & Passed \\
\hline \#94 & 27.1 & 9.4 & 0.50 & 0.30 & 7.4 & Passed \\
\hline \#95 & 109.5 & 24.1 & 0.45 & 0.53 & 9.9 & Passed \\
\hline \#98 & 180.0 & 0.0 & 0.29 & - & 5.7 & Not entered \\
\hline \#99 & 142.1 & 37.8 & 0.40 & 0.32 & 8.8 & Entered \\
\hline \#102 & 75.4 & 9.2 & 0.49 & 0.39 & 3.3 & Passed \\
\hline \#103 & 135.5 & 35.5 & 0.34 & 0.40 & 4.6 & Passed \\
\hline \#106 & 180.0 & 0.0 & 0.18 & - & 0.4 & Not entered \\
\hline \#107 & 136.7 & 43.3 & 0.65 & 0.71 & 27.9 & Passed \\
\hline
\end{tabular}

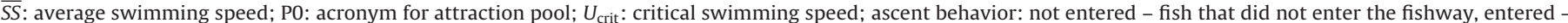
fish that entered the fishway but did not successfully ascend the entire structure, passed - fish that successfully ascended the fishway.
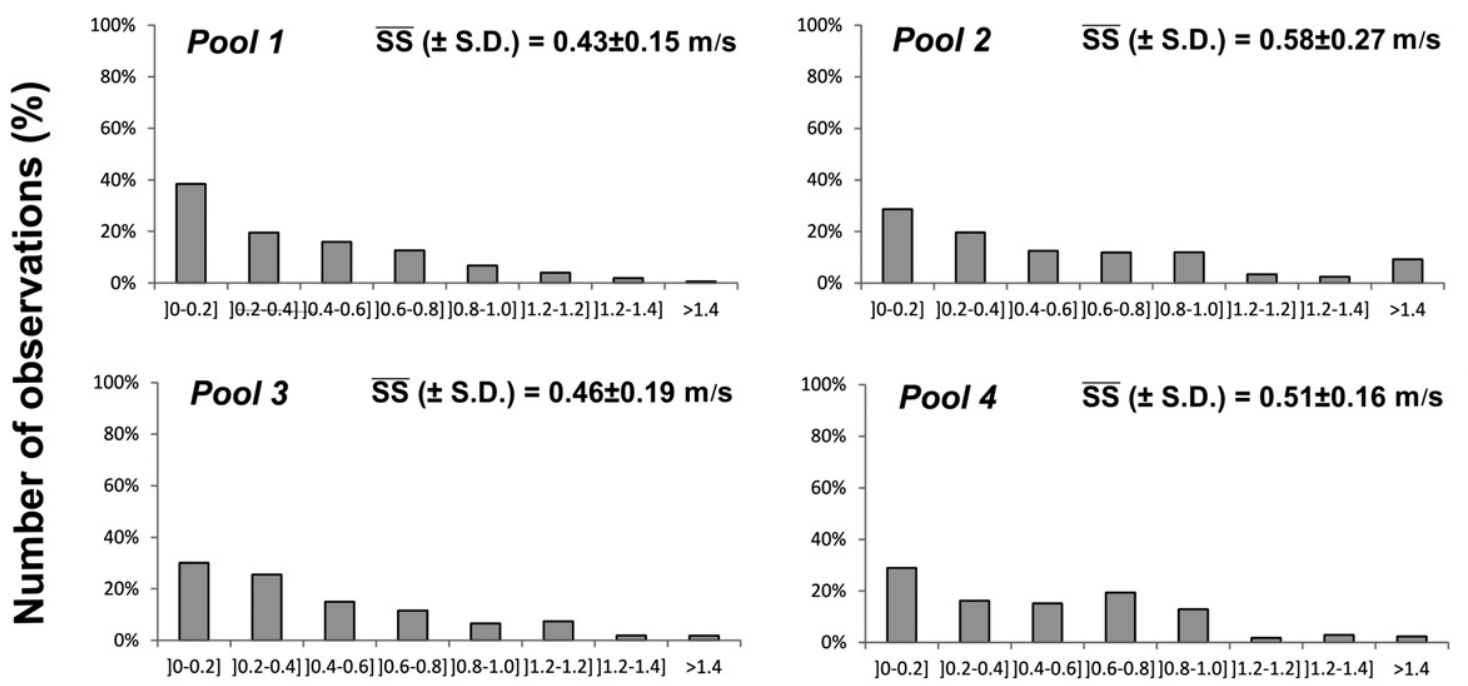

\section{Swimming speed $(\mathrm{m} / \mathrm{s})$}

Fig. 2. Swimming speeds $(\mathrm{m} / \mathrm{s})$ recorded with tagged barbels during the passage time in pools (Pool 1-Pool 4) of the experimental fishway. $\overline{S S}$ : average swimming speed.

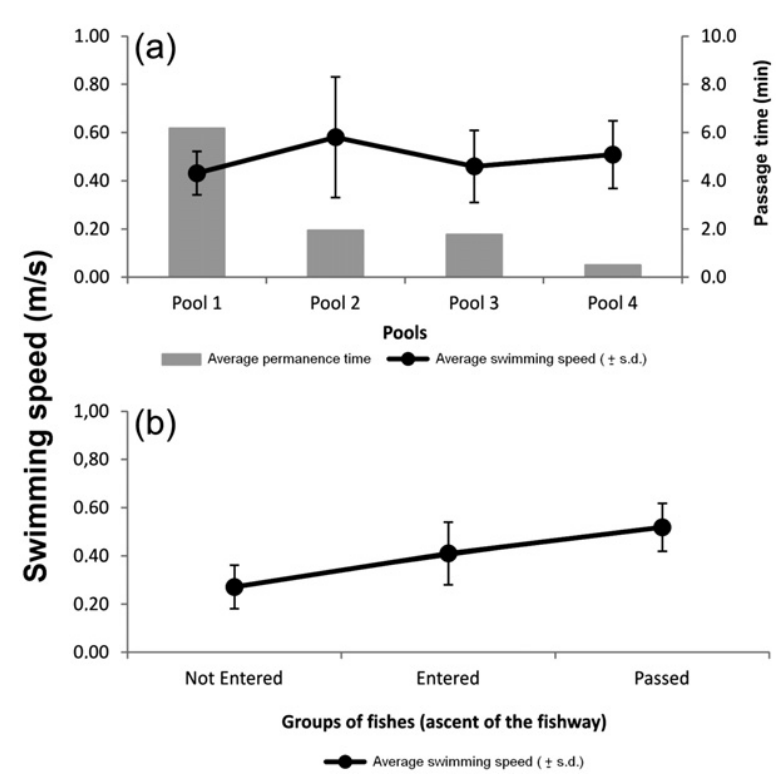

Fig. 3. Average swimming speed $(\mathrm{m} / \mathrm{s})$ and passage time $(\mathrm{min})$ in the four pools (Pool 1-Pool 4) of the experimental fishway (a) and average swimming speed exhibited in the attraction pool (P0) by the three groups of fishes (b).
Fig. 4 presents a typical swimming speed vs. time graph for a selected barbel (\#103) that completely ascended the fishway. Anaerobic burst swimming (above $U_{\text {crit }}$ ) was only required to move through the submerged orifices of the fishway, since the majority of the barbels' swimming velocities during that period were below the theoretical $U_{\text {crit }}$ levels for a barbel of that particular $L_{\mathrm{t}}$. The proportion of time spent by the tagged barbels below the theoretical $U_{\text {crit }}$ was much higher than the proportion of time spent above this value.

From the nine barbels that entered the fishway into any of the pools or that completely passed through it, five manage to ascend it at least two times allowing the comparison of swimming speed frequencies between the first and the second passage (Fig. 5). Most of the analyzed barbels did not exhibited significant swimming speed differences between the first and second fishway ascents, with the exception of fish \#102 and \#107 who presented a significantly higher proportion of the lower swimming speed classes during the second fishway ascent $\left(\chi^{2}=190.04 ; P<0.001\right.$ and $\chi^{2}=85.13$; $P<0.001$, respectively). On the other hand, the total amount of time that barbels spent to ascend the fishway for the second time was significantly lower (Wilcoxon's test; $Z=5.031 ; P<0.05$ ) than the time spent for the first passage.

Eight of the tested barbels entered the second downstream pool (P1) and successfully surpassed it at least one time, allowing 


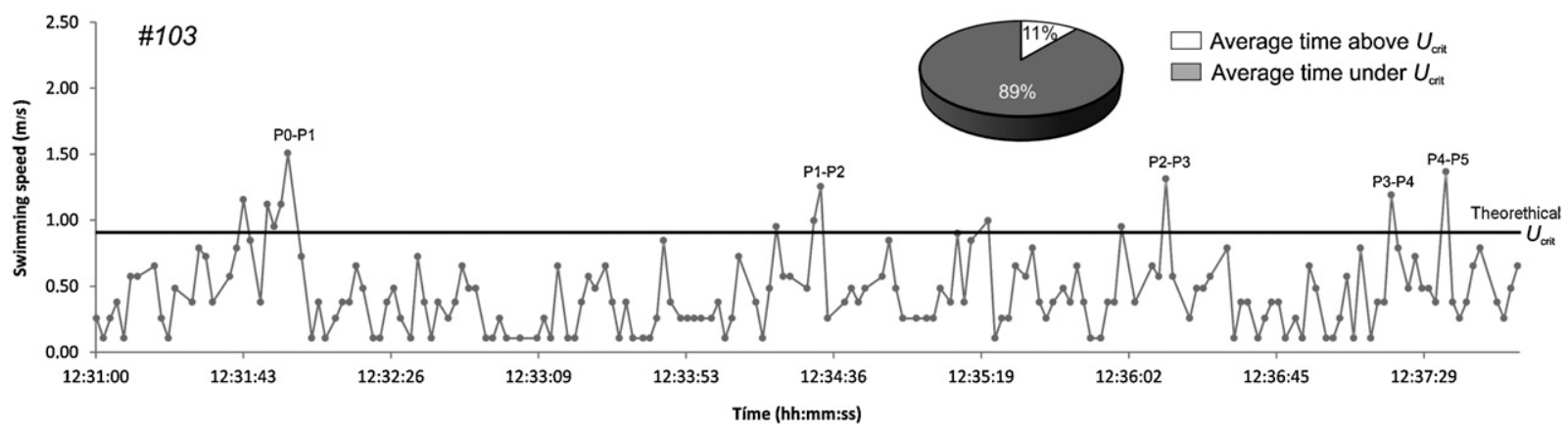

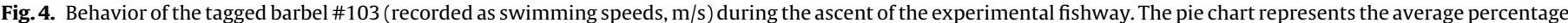

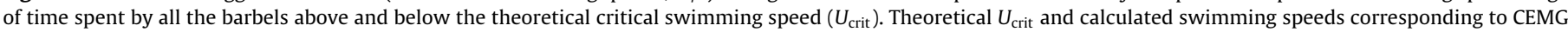

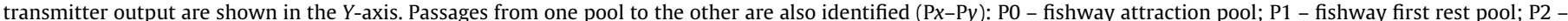
fishway second rest pool; P3 - fishway third rest pool; P4 - fishway fourth rest pool; P5 - fishway upstream pool.

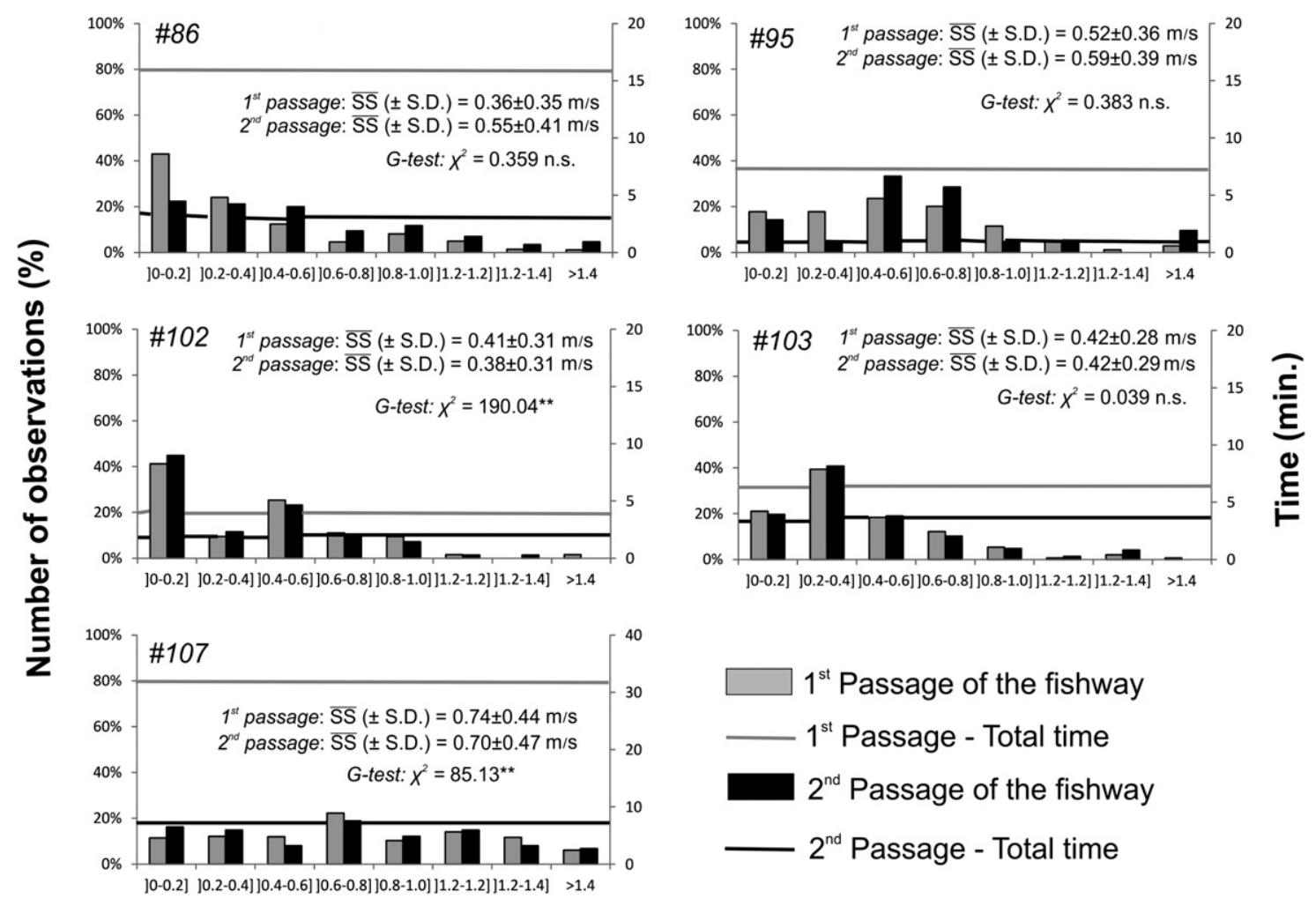

Swimming speed $(\mathrm{m} / \mathrm{s})$

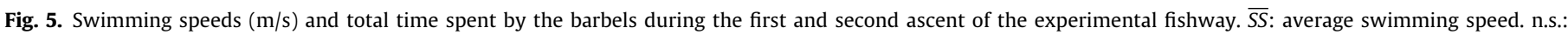
non-significant; ${ }^{* *} P$-value $<0.001$.

Table 3

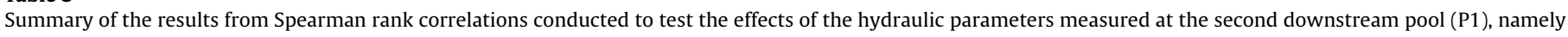

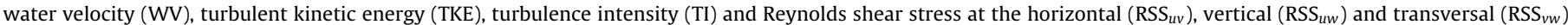
planes, on fish swimming speed.

\begin{tabular}{|c|c|c|c|}
\hline Dependent variable & Independent variables & Spearman rank test, $\rho$ & $P$-value \\
\hline \multirow{6}{*}{ Swimming speed (m/s) } & $\mathrm{WV}(\mathrm{m} / \mathrm{s})$ & 0.22 & $<0.001$ \\
\hline & $\operatorname{TKE}\left(\mathrm{m}^{2} / \mathrm{s}^{2}\right)$ & 0.33 & $<0.001$ \\
\hline & $\mathrm{TI}$ & 0.22 & $<0.001$ \\
\hline & $\mathrm{RSS}_{u v}\left(\mathrm{~N} / \mathrm{m}^{2}\right)$ & 0.53 & $<0.001$ \\
\hline & $\mathrm{RSS}_{u w}\left(\mathrm{~N} / \mathrm{m}^{2}\right)$ & 0.04 & 0.093 \\
\hline & $\mathrm{RSS}_{v w}\left(\mathrm{~N} / \mathrm{m}^{2}\right)$ & -0.02 & 0.435 \\
\hline
\end{tabular}



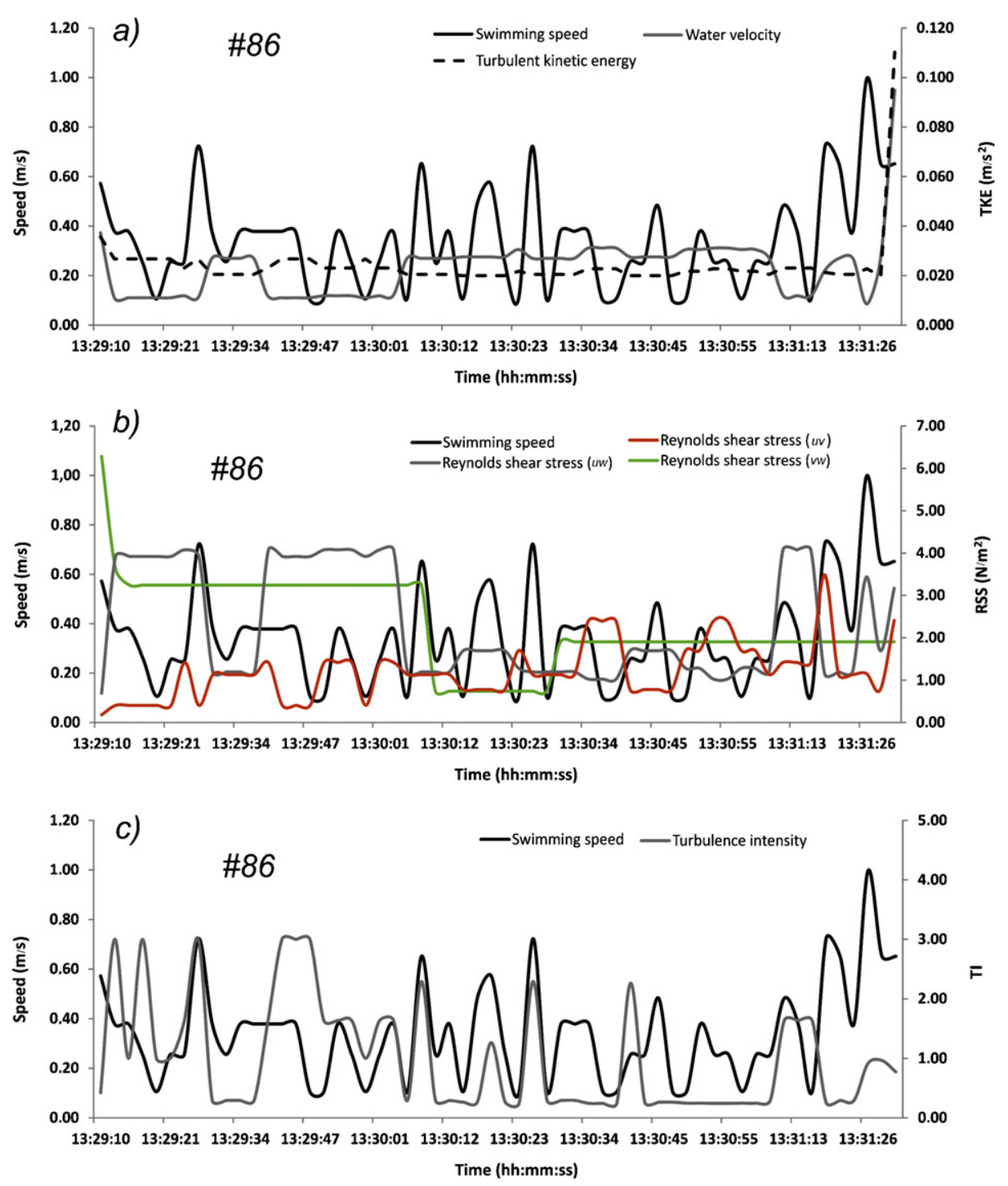

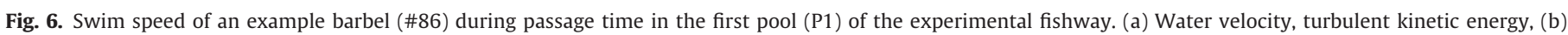

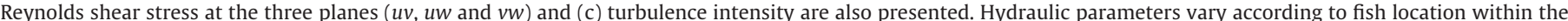
pool.

the collection of suitable data for assessing the effects of the hydraulic variables on fish swimming speed within each one of the grid cells. Regarding this analysis, a significant positive relation between swimming speed and mean $\operatorname{WV}(\rho=0.22 ; P<0.001)$ was found for the tested fishes (Table 3; Fig. 6). A similar relationship with fish swim speed was also found for TKE $(\rho=0.33$; $P<0.001)$ and for TI $(\rho=0.22 ; P<0.001)$. Like the previous parameters, the horizontal vector of RSS was found to be significantly correlated with swimming speed $(\rho=0.53 ; P<0.001)$. Of all the hydraulic variables tested, this was the one that exhibited the highest correlation coefficient with barbels' swim speed. No significant correlations were found between fish swimming speed and the other two RSS vectors, namely the vertical and transversal planes.

\section{Discussion}

Studies analyzing the swimming behavior of fish according to different physiological and environmental conditions can provide valuable tools for environmental managers to assess the quality of the aquatic environment and its effects on target species. For example, a manager that wishes to improve the design of a fishway to allow the passage of a target fish species can use these data to determine the adequate hydraulic arrangement to increase the efficiency of that facility (Peake et al., 1997). Knowledge of fish biological response within fishways can also be used to develop or improve computer models often used by engineers to evaluate the efficiency of old or new fishway designs (Puertas et al., 2012). By allowing the physiological analysis of fish swimming speed variations and energetic costs related with different hydraulic scenarios, the output resulting from the use of these transmitters bridges a gap associated to fishway designs based purely on swim tunnel performance, which in some cases does not accurately reflect real field performances (Peake, 2004). The work described in the present study is particularly novel in its area because it represents the first attempt to analyze a cyprinid behavior within an experimental pool-type fishway, where several hydraulic conditions and structural designs can be simulated, by using not only the direct observation of fish but also more detailed and instantaneous information about fish physiological response to different hydraulic conditions, through the use of EMG sensors that record axial musculature activity. 
Highly significant regressions were obtained between CEMG transmitter output and swim speed, which reveals that this technology is a good indicator of swimming activity, and thus behavior, of this species in the wild. Also, during the calibration procedure, all tagged barbels performed well in the swimming chamber and did not seem to be affected by the transmitters' implantation in terms of swimming capacity and behavior when compared with the Mateus et al. (2008) study. These results clearly validate the use of electromyogram telemetry as a method to study barbel swimming physiology and reveal its potential to be used in future studies about this species behavior while moving through fishways or other hydraulic structures. Moreover, our findings corroborate other telemetry studies, focusing on different species, which validate the use of electromyogram telemetry as a method to study fish swimming physiology and recommend its use for the assessment of fishway efficiency for the respective targeted species. (Almeida et al., 2007; Brown et al., 2007; Hinch et al., 1996; Økland et al., 1997; Thorstad et al., 2000). Despite the strong potential of this type of transmitters, there are some issues that must be taken into account in future applications of this methodology. EMG output and swimming speed relationships significantly differed among tested barbels. Therefore, considering the results from this study and previous ones (Brown et al., 2007; Cooke et al., 2004; Geist et al., 2002; Thorstad et al., 2000), all fish implanted with EMG transmitters should be individually calibrated prior to release to be able to determine their specific instantaneous swimming speed with the electromyogram records. Also, during the calibration procedure, unsteady swimming and, consequently, less homogeneous CEMG records at higher speeds (generally above $1.0 \mathrm{~m} / \mathrm{s}$ ) were observed in most fish. According to several authors that had the same results with different species (Almeida et al., 2007; Thorstad et al., 2000), this behavior is probably related to a less uniform swimming behavior near the $U_{\text {crit }}$. At high speeds of burst swimming, which can be frequently required in poor designed or unsuitable fishways, the red muscle recruitment decreases while the intensity of white muscle activity increases (Jain and Lauder, 1994). In fact, in some of the tagged barbels the CEMG signals recorded at the highest speeds decreased. Therefore, in future fishway evaluations using this telemetry method, one should have in mind that the higher swimming speed records may be underestimated with this sampling technique if the electrodes are implanted in the red axial musculature.

Learning to use the favorable flow patterns to swim during fishway ascent has been suggested as an explanation of fish improved movement through these facilities (Laine, 1990). Theoretically, in this study, during the successive passages of four pools with similar flow conditions or between two complete fishway ascents, it was expected that the barbels would acquire some knowledge of the flow patterns within the experimental facility and, therefore, would choose more stable areas that require less muscular effort to negotiate the obstacle. This assumption was not demonstrated in this study, since the tagged barbels did not exhibit significant differences in swimming speed between any of the four pools and only two of them presented a distinct swim speed frequency distribution between the first and second fishway ascent. Regardless of this, significant differences were found between the four pools when the compared variable was the passage time. Also, barbels spent significantly less time to perform the second complete ascent of the fishway when compared to the first one and the time was consistently reduced in following passes. The "learning" pattern found in this study was mostly reflected in the knowledge of how to get in and out of the pools and of the entire fishway and it probably takes more time, and attempts, for the fishes to learn how to perform a less physiologically demanding path. These results have to be looked carefully because of the relatively low sample size of fish that performed a second fishway ascent and more tests, with a prolonged duration than this one and in larger fishways, should be conducted using EMG transmitters to further clarify this issue. In a study developed by Collins et al. (1962) with salmonids in an experimental fishway, it took almost two days of passage attempts before the fishes started to show an increase in passage success rate and a decrease in the blood-lactate level, used as an index of muscular fatigue, after the fishway ascent.

In the present study, barbels with different activity levels in the attraction pool also obtained distinct success in ascending the fishway. Fishes that completely ascended the fishway exhibited higher average swimming speed values in the first downstream pool than the ones that only ascended to the middle of the structure or did not leave the attraction pool during the entire trial, somehow making it possible to predict the fish passage success based on their level of activity in the fishway entrance. Nonetheless, the hydraulic conditions (flow patterns, water velocity and flow discharges) in the vicinity of the entrance of a fishway are the main factor determining its' attraction (Larinier, 2002). As cited by Scruton et al. (2007), previous work performed in fishways determined that Atlantic salmon (Salmo salar L.) may spend several days milling at the fishway entrance and making attempts to enter it before proceeding through the fishway. This could mean that, in this study, barbels that did not enter the fishway during the established trial period, eventually, might have entered later. More studies concerning these aspects of fishway design and operation, using a higher number of fish and different hydraulic conditions, should be conducted in order to clarify this question.

The EMG telemetry applied revealed that barbels had to exceed their critical swimming speed (defined by Mateus et al., 2008) only during passage through the submerged orifices. Although fishway ascent was not too much energetically demanding for barbels, observations of burst swimming while passing the orifices suggest that energy use could be high at these points (Pon et al., 2009). This has been also reported by Booth et al. (1997), who found that, for Atlantic salmon, the ascent of an experimental fishway may involve activity beyond its aerobic scope. These authors described a rapid increase in salmon muscular activity to above $U_{\text {crit }}$ values, which remained elevated throughout the fishway ascent. Previous studies have shown that a significant oxygen debt is acquired during fish anaerobic activity (Wood et al., 1983) and the energetic costs of recovering from this may be greater than their aerobic scope (Beamish, 1978). The fishway configuration analyzed in this study through the use of EMG proved to be adequate for the successful passage of the target species confirming previous studies conducted in the same hydraulic infrastructure (Silva et al., 2009, 2011, 2012b). However, even successful passage through a fishway can have deleterious effects on fish that could lead to delayed mortality and negatively affect fish fitness to the point of upsetting the posterior success of their spawning migration and reproduction (Brown et al., 2006; Gowans et al., 2003). In a study to evaluate the post-fishway passage survival and reproductive success of sockeye salmon (Oncorhynchus nerka), Roscoe et al. (2011) found that the fish passage through a tail race and a vertical slot fishway involving anaerobic activity, had a significant impact on the success of the species spawning migration since approximately half of the migrating adults that passed upstream through these structures failed on reaching spawning grounds. Hinch and Bratty (2000), using the same EMG technique to evaluate the fishway passage of sockeye salmons found that fish that spent longer time periods ( $>10 \mathrm{~min}$ ) above their $U_{\text {crit }}$ could not complete their upstream migration even after fishway negotiation in opposition to fish that spent reduced periods under $U_{\text {crit }}$, which were successful migrants. According to Prchalová et al.(2006), several freshwater cyprinids (bleak Alburnus alburnus L., barbel Barbus barbus L., roach Rutilus rutilus L. and dace 
Leuciscus leuciscus L.) use fish passes not only during their spawning migrations but also during other periods of the year. Smaller barbels than the ones used in the present study, for which the $U_{\text {crit }}$ values differ significantly (Mateus et al., 2008), can more easily exceed their aerobic scope and stay for longer periods above it, thus suffering from post-passage effects, an issue that fishway designers and engineers should take into account when implementing this type of structures. However, according to Penáz et al. (2002) the proportion of mobile barbels is relatively low in smaller and middle size classes, increasing for the larger classes, which makes the latter a more important study object when dealing with connectivity problems.

This study showed the existence of a positive relationship between barbels' swimming speed and some hydraulic variables, namely the water velocity, turbulent kinetic energy, turbulence intensity and horizontal Reynolds shear stress, highlighting the importance of these parameters when building fishways for this species. The swimming speed exhibited by Iberian barbels was lower in cells with reduced water velocity and turbulence, implying that in these areas the barbels had to do less muscular effort to maintain their position (Enders et al., 2007; Pavlov et al., 2000). These conditions were primarily found near the bottom of the fishway, on the recirculation zone, where fishes were found to spend most of their time during the fishway ascent. Several studies have shown that recirculation areas on pool-type fishways can become traps for fishes, drastically increasing the transit time in each pool and thus compromising the passage through the facility (Tarrade et al., 2008). Despite the fact that this phenomenon could have affected some of the fishes tested in this study, the high proportion of barbels that successfully negotiated the fishway in a relatively short period, indicates that most of the fish used these areas essentially for resting before moving toward higher velocity and more turbulent regions in the vicinity of the orifices, where burst swimming was required. These anaerobic swimming efforts, apparently recruiting fast-glycolytic (white) muscle to ascend the flume, are very powerful, but rest and recovery periods are necessary to clear muscle $\mathrm{H}^{+}$and lactate build-ups and to restore glycogen stores, as shown for rainbow trout (Milligan and Wood, 1986). However, this study was performed under controlled laboratorial conditions and the high permanence time in these resting areas could have had other negative impacts on barbels if we were dealing with a real fishway in the field, since delayed fishway passages could also result in increased predation (Hinch and Bratty, 2000; Pelicice and Agostinho, 2008).

Reynolds shear stress, in particular its horizontal component, was found to be the hydraulic variable with the highest influence on fish swimming speed, suggesting the importance of this turbulent descriptor on barbels' behavior and physiological response within this type of fishway. The maximum shear stress values obtained in the present study (near $0.080 \mathrm{~N} / \mathrm{m}^{2}$ ) were far from those reported to cause injuries or mortalities on fishes (Cada et al., 2006). However, according to the results presented in this study, in areas with higher shear stress, some disorientation may have happened, due to the effect of larger turbulence vortex systems on the fish body surface (Odeh et al., 2002), and the tagged barbels had to perform at a higher muscular cost to maintain their position until moving forward or being dragged downstream. Silva et al. (2011, 2012a,b), when studying the relationship of these hydraulic variables with fish transit time within the fishway, found that barbels tend to spend less time on areas with high velocity, turbulence and shear stress. These results support the ones obtained in the present study, thus implying that during the fishway ascent barbels tend to spend more time in stable zones, avoiding turbulent areas where the energy expenditure and muscular effort would increase to values near their critical swimming speed and only moving to more turbulent areas when trying to pass the orifice to the upstream pool. Other authors presented similar results for different species indicating that turbulence and other associated measures like shear stress tend to induce higher fish swimming costs (Cocherell et al., 2011; Enders et al., 2007; Tritico and Cotel, 2010). On the other hand, Lupandin (2005) describes a negative relationship between turbulence and swimming performance, mostly reflected on a loss of balance and a consequent decrease in fish swimming speed when facing high turbulence, contradicting our results. However, this author used a different methodology, implementing flow increments until a turbulence level was reached that was high enough for the fish to give up swimming and be carried downstream, measuring the hydraulic value at that point. Our study provides more precise and almost instantaneous information about the muscular effort ( $2 \mathrm{~s}$ average) exhibited by fishes to maintain their swimming position in different hydraulic conditions, a result only possible with the use of electromyogram telemetry.

EMG telemetry technology has been, and can be, used in several fields of fish research allowing a reliable estimate of muscle activity (or swim speed) and thus energy expenditure in field experiments. In this study, this technology offered valuable and detailed information about fish movements, behavior and relationship with the hydraulic environment, which can be used to improve the design of these structures, allowing the migration and access to new habitats of fish species with minimum energy expenditure. New fishways or adaptations made to old ones can be planned and adjusted to fit the capacity of the target species. Biologists and engineers may be able to use EMG telemetry to determine where and how to restore river environments in order to facilitate fish migration (Hinch et al., 1996). This study demonstrated that radio transmitted CEMG signals can be used to determine the swim speed and thus the behavior of $L$. bocagei and to evaluate fishway design in relation to their efficiency for this particular species, opening good perspectives for the applicability of this technique to similar cyprinids.

\section{Acknowledgements}

The authors wish to thank to Sara Pinela, Sílvia Pedro and Vera Canastreiro for their assistance during fish sampling campaigns. Special thanks are due to the Division of Water Resources and Hydraulics Structures of the National Laboratory for Civil Engineering for their collaboration, namely for the contribution in the design of the experimental fishway and for all the assistance during the fish trials. Licensing to collect the specimens was provided by Autoridade Florestal Nacional (AFN). This work was financially supported by the Science and Technology Foundation through grants to Carlos Alexandre (SFRH/BD/66081/2009) and Paulo Branco (SFRH/BD/44938/2008) and through its pluriannual funding program to the Centre of Oceanography (PEst-OE/MAR/UI0199/2011).

\section{References}

Almeida, P.R., Póvoa, I., Quintella, B.R., 2007. Laboratory protocol to calibrate sea lamprey (Petromyzon marinus L.) EMG signal output with swimming. Hydrobiologia 582, 209-220.

Alvarez-Vázquez, L.J., Martínez, A., Vázquez-Méndez, M.E., Vilar, M.A., 2007. An optimal shape problem related to the realistic design of river fishway. Ecol. Eng. 32, 293-300.

Anderson, M.J., Gorley, R.N., Clarke, K.R., 2008. PERMANOVA for PRIMER: Guide to Software and Statistical Methods. PRIMER-E Ltd., Plymouth, United Kingdom, 214 pp.

Baras, E., Cherry, B., 1990. Seasonal activities of female barbel Barbus barbus (L.) in the River Ourthe (Southern Belgium), as revealed by radio tracking. Aquat. Living Resour. 3, 283-294.

Baras, E., Lambert, H., Philippart, J.C., 1994. A comprehensive assessment of the failure of Barbus barbus spawing migrations through a fish pass in the canalized River Meuse (Belgium). Aquat. Living Resour. 7, 181-189.

Beamish, F., 1978. Swimming capacity. In: Hoar, W.S., Randall, D.J. (Eds.), Fish Physiology. Academic Press, New York, pp. 101-187. 
Beddow, T.A., McKinley, R.S., 1999. Importance of electrode positioning in biotelemetry studies estimating muscle activity in fish. J. Fish Biol. 54, 819-831.

Booth, R.K., McKinley, R.S., Økland, F., Sisak, M.M., 1997. In situ measurement of swimming performance of wild Atlantic salmon (Salmo salar) using radio transmitted electromyogram signals. Aquat. Living Resour. 10, 213-219.

Brown, R.S., Geist, D.R., Mesa, M.G., 2006. Use of electromyogram telemetry to assess swimming activity of adult spring Chinook salmon migrating past a Columbia River dam. Trans. Am. Fish. Soc. 135, 281-287.

Brown, R.S., Tatara, C.P., Stephenson, J.R., Berejikian, B.A., 2007. Evaluation of a new coded electromyogram transmitter for studying swimming behaviour and energetics in fish. N. Am. J. Fish. Manage. 27, 765-772.

Bunt, C.M., 1999. A tool to facilitate implantation of electrodes for electromyographic telemetry experiments. J. Fish Biol. 55, 1123-1128.

Bunt, C.M., Castro-Santos, T., Haro, A., 2012. Performance of fish passage structures at upstream barriers to migration. River Res. Appl. 28, 457-478.

Cabral, M.J. (coord), Almeida, J., Almeida, P.R., Dellinger, T., Ferrand de Almeida, N., Oliveira, M.E., Palmeirim, J.M., Queiroz, A.I., Rogado, L., Santos-Reis, M. (Eds.), 2005. Livro Vermelho dos Vertebrados de Portugal, Instituto de Conservação da Natureza, Lisboa.

Cada, G., Loar, J., Garrison, L., Fisher, R., Neitzel, D., 2006. Efforts to reduce mortality to hydroelectric turbine-passed fish: locating and quantifying damaging shear stresses. Environ. Manage. 37, 898-906.

Clay, C.H., 1995. Design of fishways and other fish facilities, 2nd ed. Lewis Publishers, Boca Raton, LA, 248 pp.

Cocherell, D.E., Kawabata, A., Kratville, D.W., Cocherell, S.A., Kaufman, R.C., Anderson, E.K., Chen, Z.Q., Bandeh, H., Rotondo, M.M., Padilla, R., Churchwell, R., Kavvas, L.M., Cech Jr., J.J., 2011. Passage performance and physiological stress response of adult white sturgeon ascending a laboratory fishway. J. Appl. Ichthyol. 27, 327-334.

Collins, G.B., Gauley, J.R., Elling, C.H., 1962. Ability of salmonids to ascend high fishways. Trans. Am. Fish. Soc. 91 (1), 1-7.

Cooke, S.J., Thorstad, E.B., Hinch, S.G., 2004. Activity and energetics of free-swimming fish: insights from electromyogram telemetry. Fish Fish. 5, 21-52.

Cowx, I.G., Welcomme, R.L., 1998. Rehabilitation of Rivers for Fish. Oxford, Fishing New Books.

Doadrio, I., 2001. Atlas y libro rojo de los peces continentales de España. Madrid, Museo Nacional de Ciencias Naturales.

Dynesius, M., Nilsson, C., 1994. Fragmentation and flow regulation of river systems in the northern third of the world. Science 266, 753-762.

Ead, S.A., Katopodis, C., Sikora, G.J., Rajaratnam, N., 2004. Flow regimes and structure in pool and fishways. J. Environ. Eng. Sci. 3, 379-390.

Enders, E.C., Smokorowski, K.E., Pennell, C.J., Clarke, K.D., Sellars, B., Scruton, D.A 2007. Habitat use and fish activity of landlocked Atlantic salmon and brook charr in a newly developed habitat compensation facility. Hydrobiologia 582 $133-142$.

European Commission, 2000. Directive 2000/60/EC of the European Parliament and of the Council of 23 October 2000 establishing a framework for the Community action in the field of water policy. Off. J. Eur. Comm.-Legis. 327, 1-72.

Geist, D.R., Brown, R.S., Lepla, K., Chandler, J., 2002. Practical application of electromyogram radiotelemetry: the suitability of applying laboratory-acquired calibration data to field data. N. Am. J. Fish. Manage. 22, 474-479.

Gowans, A.R., Armstrong, J.D., Priede, I.G., Mckelvey, S., 2003. Movements of Atlantic salmon migrating upstream through a fish-pass complex in Scotland. Ecol. Freshw. Fish 12, 177-189.

Guiny, E., Armstrong, J.D., Ervine, D.A., 2003. Preferences of mature male brown trout and Atlantic salmon parr for orifice and weir fish pass entrances matched for peak velocities and turbulence. Ecol. Freshw. Fish 12, 190-195.

Hinch, S.G., Bratty, J.M., 2000. Effects of swim speed and activity pattern on success of adult sockeye salmon migration through an area of difficult passage. Trans. Am. Fish. Soc. 129, 604-612.

Hinch, S.G., Diewert, R.E., Lissimore, T.J., Prince, M.J., Healey, M.C., Henderson, M.A., 1996. Use of electromyogram telemetry to access difficult passage areas for river-migrating adult sockeye salmon. Trans. Am. Fish. Soc. 125, 253-260.

Jager, H.I., Chandler, J.A., Lepla, K.B., Winkle, W.V., 2001. A theoretical study of river fragmentation by dams and its effects on white sturgeon populations. Environ. Biol. Fish. 60, 347-361.

Jain, B.C., Lauder, G.V., 1994. How swimming fish use slow and fast muscle fibres: implications for models of vertebrate muscle recruitment. J. Comp. Physiol. 175 , 123-131.

Jepsen, N., Koed, A., Thorstad, E.B., Baras, E., 2002. Surgical implantation of telemetry transmitters in fish: how much have we learned? Hydrobiologia 483, 239-248.

Jungwirth, M., Muhar, S., Schmutz, S., 2000. Fundamentals of fish ecological integrity and their relation to the extended serial discontinuity concept. Hydrobiologia 422, 85-97.

Kaseloo, P.A., Weatherley, A.H., Lotimer, J., Farina, M.D., 1992. A biotelemetry system recording fish activity. J. Fish Biol. 40, 165-179.

Katopodis, C., 2005. Developing a toolkit for fish passage, ecological flow management and fish habitat works. J. Hydraul. Res. 43, 451-467.

Knaepkens, G., Maerten, E., Eens, M., 2007. Performance of a pool-and-weir fish pass for small bottom-dwelling freshwater fish species in a regulated lowland river. Anim. Biol. 57 (4), 423-432.

Laine, A., 1990. The effects of a fishway model hydraulics on the ascent of vendance, whitefish and brown trout in Inari, northern Finland. Aqua Fenn. 20, 191-198.
Laine, A., Jokivirta, T., Katopodis, C., 2002. Atlantic salmon, Salmo salar L., and sea trout Salmo trutta L. passage in a regulated northern river-fishway efficiency, fish entrance and environmental factors. Fish. Manage. Ecol. 9, 65-77.

Larinier, M., 2002. Pool fishways, pre-barrages and natural bypass channels. Bull. Fr. Peche Prot. Milieux Aquat. 364 (Suppl.), 54-82.

Liu, M., Rajaratnam, N., Zhu, D., 2006. Mean flow and turbulence structure in vertical slot fishways. J. Hydraul. Eng. 132, 765-777.

Lobón-Cerviá, J., Fernández-Delgado, C., 1984. On the biology of the barbel (Barbus barbus bocagei) in the Jarama river. Fol. Zool. 33, 371-384.

Lucas, M.C., Baras, E., 2001. Migration of Freshwater Fishes. Blackwell Science, Oxford, UK.

Lucas, M.C., Frear, P.A., 1997. Effects of a flow-gauging weir on the migratory behaviour of adult barbel, a riverine cyprinid. J. Fish Biol. 50, 382-396.

Lupandin, A.I., 2005. Effect of flow turbulence on swimming speed of fish. Biol. Bull. $32,461-466$

Magalhães, M.F., 1992. Feeding ecology of the Iberian cyprinid Barbus bocagei Steindachner, 1865 in a lowland river. J. Fish Biol. 40, 123-133.

Mateus, C.S., Quintella, B.R., Almeida, P.R., 2008. The critical swimming speed of Iberian barbel Barbus bocagei in relation to size and sex. J. Fish Biol. 73, 1783-1789.

Milligan, L.C., Wood, C.M., 1986. Tissue intracellular acid-base status and the fate of lactate after exhaustive exercise in the rainbow trout. J. Exp. Biol. 123, 123-144.

Naughton, G.P., Caudill, C.C., Peery, C.A., Clabough, T.S., Jepson, M.A., Bjornn, T.C., Stuehrenberg, L.C., 2007. Experimental evaluation of fishway modifications on the passage behaviour of adult Chinook salmon and steelhead at Lower Granite Dam, Snake River, USA. River Res. Appl. 23, 99-111.

Nilsson, C., Reidy, C.A., Dynesius, M., Revenga, C., 2005. Fragmentation and flow regulation of the world's large river systems. Science 308, 405-408.

Noonan, M.J., Grant, J.W.A., Jackson, C.D., 2012. A quantitative assessment of fish passage efficiency. Fish Fish., http://dx.doi.org/10.1111/j.1467-2979.2011.00445.x

Odeh, M., Noreika, J.F., Haro, A., Maynard, A., Castro-Santos, T., 2002. Evaluation of the Effects of Turbulence on the Behavior of Migratory Fish. Final Report to the Bonneville Power Administration, Contract 00000022, Project 200005700 , Portland, OR.

Økland, F., Finstad, B., McKinley, R.S., Thorstad, E.B., Booth, R.K., 1997. Radiotransmitted electromyogram signals as indicators of physical activity in Atlantic salmon. J. Fish Biol. 51, 476-488.

Oliveira, J.M., Ferreira, A.P., Ferreira, M.T., 2002. Intrabasin variations in age and growth of Barbus bocagei populations. J. Appl. Ichthyol. 18, 134-139.

Pavlov, D.S., Lupandin, A.I., Skorobogatov, M.A., 2000. The effects of flow turbulence on the behavior and distribution of fish. J. Ichthyol. 40, S232-S261.

Peake, S., 2004. An evaluation of the use of critical swimming speed for determination of culvert water velocity criteria for smallmouth bass. Trans. Am. Fish. Soc. $133,1472-1479$

Peake, S., McKinley, R.S., Scruton, D.A., 1997. Swimming performance of various freshwater Newfoundland salmonids relative to habitat selection and fishway design. J. Fish Biol. 51, 710-723.

Pelicice, F.M., Agostinho, A.A., 2008. Fish-passage facilities as ecological traps in large neotropical rivers. Conserv. Biol. 22, 180-188.

Penáz, M., Barus, V., Prokes, M., Homolka, M., 2002. Movements of barbel, Barbus barbus (Pisces: Cyprinidae). Folia Zool. 51, 55-66.

Pon, L.B., Hinch, S.G., Cooke, S.J., Patterson, D.A., Farrell, A.P., 2009. Physiological, energetic and behavioral correlates of successful fishway passage of adult sockeye salmon Oncorhynchus nerka in the Seton River, British Columbia. J. Fish Biol. $74,1323-1336$

Poulet, N., 2007. Impact of weirs on fish communities in a piedmont stream. River Res. Appl. 23, 1038-1047.

Prchalová, M., Vetesnik, L., Slavik, O., 2006. Migrations of juvenile and subadult fish through a fishpass during late summer and fall. Folia Zool. 55, 162-166.

Puertas, J., Cea, L., Bermúdez, M., Pena, L., Rodriguez, A., Rabuñal, J.R., Balairón, L., Lara, A., Aramburu, E., 2012. Computer application for the analysis and design of vertical slot fishways in accordance with the requirement of the target species. Ecol. Eng. 48, 51-60.

Quintella, B.R., Andrade, N.O., Koed, A. Almeida, P.R., 2004. Behavioral patterns of sea lampreys' spawning migration through difficult passage areas, studied by electromyogram telemetry. J. Fish Biol. 65, 961-972.

Rodríguez-Ruiz, A., Granado-Lorencio, C., 1992. Spawning period and migration of three species of cyprinids in a stream with Mediterranean regimen (SW Spain). J. Fish Biol. 41, 545-556.

Roscoe, D.W., Hinch, S.G., 2010. Effectiveness monitoring of fish passage facilities: historical trends, geographic patterns and future directions. Fish Fish.11,12-33.

Roscoe, D.W., Hinch, S.G., Cooke, S.J., Patterson, D.A., 2011. Fishway passage and post-passage of up-river migrating sockeye salmon in the Seton River, British Columbia. River Res. Appl. 27, 693-705.

Santos, J.M., Ferreira, M.T., Godinho, F.N., Bochechas, J., 2005. Efficacy of a nature-like bypass channel in a Portuguese lowland river. J. Appl. Ichthyol. 21, 381-388.

Santos, J.M., Silva, A.T., Katopodis, C., Pinheiro, P., Pinheiro, A., Bochechas, J., Ferreira, M.T., 2012. Ecohydraulics of pool-type fishways: getting past the barriers. Ecol. Eng. 48, 38-50.

Scruton, D.A., Booth, R.K., Pennell, C.J., Cubbit, F., McKinley, R.S., Clarke, K.D., 2007. Conventional and EMG telemetry studies of upstream migration and tailrace attraction of adult Atlantic salmon at a hydroelectric installation on the Exploits River, Newfoundland, Canada. Hydrobiologia 582, 67-79.

Siegel, S., Castellan, N.J., 1988. Nonparametric Statistics for the Behavioral Sciences. McGraw-Hill, New York. 
Silva, A.T., Katopodis, C., Santos, J.M., Ferreira, M.T., Pinheiro, A.N., 2012a. Cyprinid swimming behaviour in response to turbulent flow. Ecol. Eng. 44, 314-328.

Silva, A.T., Santos, J.M., Franco, A.C., Ferreira, M.T., Pinheiro, A.N., 2009. Selection of Iberian barbel Barbus bocagei (Steindachner, 1864) for orifices and notches upon different hydraulic configurations in an experimental pool-type fishway. J. Appl. Ichthyol. 25, 173-177.

Silva, A.T., Santos, J.M., Ferreira, M.T., Pinheiro, A.N., Katopodis, C., 2011. Effects of water velocity and turbulence on the behaviour of Iberian barbell (Luciobarbus bocagei, Steindachner 1864) in an experimental pool-type fishway. River Res. Appl. 27, 360-373.

Silva, A.T., Santos, J.M., Ferreira, M.T., Pinheiro, A.N., Katopodis, C., 2012b. Passage efficiency of offset and straight orifices for upstream movements of Iberian barbel in a pool-type fishway. River Res. Appl. 28, 529-542.
Sokal, R.E., Rohlf, F., 1981. Biometry: The Principles and Practice of Statistics in Biological Research, 2nd ed. W.H. Freeman, New York.

Tarrade, L., Texier, A., David, L., Larinier, M., 2008. Topologies and measurements of turbulent flow in vertical slot fishways. Hydrobiologia 609, 177-188.

Thorstad, E.B., Økland, F., Koed, A., McKinley, R.S., 2000. Radio-transmitted electromyogram signals as indicators of swimming speed in lake trout and brown trout. J. Fish Biol. 57, 547-561.

Tritico, H.M., Cotel, A.J., 2010. The effects of turbulent eddies on the stability and critical swimming speed of creek chub (Semotilus atromaculatus). J. Exp. Biol 213, 2284-2293.

Wood, C.M., Turner, J.D., Graham, M.S., 1983. Why do fish die after severe exercise? J. Fish Biol. 22, 189-201. 